\title{
IMPORTANT NOVELTIES IN AUSTRIAN ANIMAL WELFARE LEGISLATION AS OF 1/4/16
}

Martina Pluda ${ }^{1}$

As of April 1, 2016 two important changes in the Austrian animal welfare legislation have entered into force: firstly, mandatory castration has been extended to all cats living in rural areas (Federal Law Gazette II Nr. 68/2016) and secondly, a ban for the sale of wild animals at fairs has been issued (Federal Law Gazette II Nr. 69/2016).

In the past the provisions regarding mandatory castration contained in the II Animal Keeping Regulation², especially the German term "bäuerliche Haltung" (literally "farm keeping"), have repeatedly led to misunderstandings and misinterpretation, as the requirement addressed cats that had access to the outdoors, excluding cats kept exclusively indoors, cats used for breeding purposes, and cats living on farms/belonging to farmers. According to the $68^{\text {th }}$ Decree of the Austrian Federal Ministry of Health, this last exception has now been deleted, leaving an exemption only for indoor and breeding cats $^{3}$. The competent Minister Sabine Oberhauser (SPÖ - Social Democratic Party), promoter of the amendment stated, "With this clarification we are helping to prevent unnecessary animal suffering. Many kittens end up in shelters or in the worst case even killed because free roaming cats mate in uncontrolled manner and their owners do not know what to do with the litters. With compulsory castration for all free-roaming cats we want to prevent such cases in the future"4.

The ban of wildlife fairs is also an important novelty for a better protection of animals as it reduces the tendency of people impulsively buying exotic species as pets. With the $69^{\text {th }}$ Decree of the Federal Ministry of Health, the Animal Welfare-Event Regulation has been amended with the introduction of $\S 2$ para. $2 a^{5}$. Minister Oberhauser said, "The purchase of these kinds of animals should be carefully considered; animal owners have a big responsibility. Spontaneously purchasing an exotic pet at a fair leads inevitably to more animal suffering, since the buyers often do not inform themselves beforehand on the keeping requirements. Therefore these kinds of fairs will be banned from now on" ${ }^{\prime \prime}$. What will still be allowed is the sale of wild animals in pet shops, where customers can be better advised on the needs of the animals, as well as their swapping at exchange fairs.

\footnotetext{
${ }^{1}$ Mag. iur., LLB. oec. Master in Animal Law and Society (4 ${ }^{\text {th }}$ Ed.), Head of Programmes (AT) Vier Pfoten Stiftung für Tierschutz.

2 Punkt 2 Abs 10 Anl. I, 2. Tierhaltungsverordnung, BGBI. II Nr. 486/2004.

${ }^{3}$ Punkt 2 Abs 10 Anl. I, 2. Tierhaltungsverordnung, BGBI. II Nr. 486/2004 idF BGBI. II Nr. 68/ 2016.

${ }^{4,5} B M G$, Oberhauser: Verbot von Wildtier-Kaufbörsen ab 1. April.

http://www.bmg.gv.at/home/Presse/Pressemeldungen/Oberhauser Verbot von Wildtier Kaufboersen ab 1 April (24.03.2016)

${ }^{5}$ Tierschutz-Veranstaltungsverordnung, BGBI. II Nr. 493/2004 idf BGBI. II Nr. 69/2016.
} 